\title{
Damage to Abies koreana seeds by soil-borne fungi on Mount Halla, Korea
}

\author{
HyeKyoung Cho, Toshizumi Miyamoto, Kunihide Takahashi, SungGak Hong, and \\ JongJin Kim
}

\begin{abstract}
Abies koreana Wilson is an endemic tree species that is facing critical population declines in Korea. To identify factors affecting the natural regeneration of A. koreana, we examined the role of seed pathogens in the overwintering survival of seeds in natural seedbeds on Mount Halla, Korea. In September 2003, seeds of A. koreana were placed on seedbeds in the following three types of sites: Sasa dominated, shaded by rocks, or forest floor; seeds were then recovered from beneath the snow cover in April 2004 and were analyzed for the occurrence of harmful microfungi. Racodium therryanum Thuem. was the fungus most often isolated from retrieved seeds and was also the most detrimental of the eight fungal species tested in a pathogenicity trial. In vitro, $R$. therryanum caused a total loss of germination ability in A. koreana seeds at $0{ }^{\circ} \mathrm{C}$ after 100 days. The infection rate of $R$. therryanum was negatively correlated with the seed germination rate. The infection rate of $R$. therryanum was highest on the forest floor and increased with the duration of snow cover. The occurrence of $R$. therryanum was temporally restricted to the period of snow cover and spatially to the thick $\mathrm{A}_{0}$ soil layer on the forest floor. This study suggests that $R$. therryanum may be a significant factor inhibiting the natural regeneration of $A$. koreana at the seed stage.
\end{abstract}

Résumé : Abies koreana Wilson est une espèce d'arbre indigène dont la population décline de façon inquiétante en Corée. Dans le but d'identifier les facteurs qui affectent la régénération naturelle d'A. koreana, nous avons étudié le rôle des pathogènes qui affectent les graines dans la survie des semences après qu'elles aient passé l'hiver dans des lits de germination naturels sur le mont Halla, en Corée. En septembre 2003, des graines d'A. koreana ont été placées sur des lits de germination dans les trois types suivants de sites : dominé par Sasa, à l'ombre de rochers ou sur le parterre forestier. Les graines ont ensuite été récupérées sous le couvert de neige en avril 2004 et examinées pour détecter la présence de champignons microscopiques nocifs. Racodium therryanum Thuem. est le champignon qui a été le plus souvent isolé des graines récupérées et ce champignon était également le plus nuisible des huit champignons testés dans un test de pathogénicité. In vitro, $R$. therryanum a causé la perte totale du pouvoir de germination des graines d'A. koreana après 100 jours à $0{ }^{\circ} \mathrm{C}$. Le taux d'infection par $R$. therryanum était négativement corrélé au taux de germination des graines. Le taux d'infection par $R$. therryanum était le plus élevé sur le parterre forestier et augmentait avec la durée du couvert de neige. L'occurrence de $R$. therryanum était restreinte dans le temps à la période durant laquelle il y avait un couvert de neige et dans l'espace à l'épais horizon $\mathrm{A}_{0}$ du sol sur le parterre forestier. Cette étude indique que $R$. therryanum peut être un facteur significatif en inhibant la régénération d'A. koreana dès le stade de la semence.

[Traduit par la Rédaction]

\section{Introduction}

Abies koreana Wilson is an endemic species in Korea. The natural distribution of $A$. koreana is restricted to the subalpine areas of Mount Halla, Mount Chiri, Mount Deokyu, and Mount Kaya, Korea (Lee and Hong 1995). However, A. koreana is facing critical population declines (Kim et al. 1998) and is a threatened species on the IUCN red list (Baillie et al. 2004). To reverse the decline of this species and preserve the genetic diversity, it is necessary to increase natural regeneration from seeds; to facilitate this natural regeneration, we need an understanding of the factors that affect seed germination and initial seedling survival.
Under natural conditions, high losses of seeds are attributable to a lack of seed viability and damage or consumption by fungi, insects, and various vertebrates (Kozlowski 1971). Lawrence and Rediske (1962) conducted a detailed appraisal of the fate of sown Pseudotsuga menziesii (Mirb.) Franco seeds. Pregermination losses amounted to $46 \%$, with fungi $(20 \%)$, insects and other invertebrates $(10 \%)$, rodents $(8 \%)$, and birds $(3 \%)$ having the greatest impact. From the beginning of seed fall until the end of germination, only $12 \%$ of $P$. menziesii seeds survived, with $63 \%$ of the loss attributable to ground-feeding birds and small mammals and $25 \%$ to other agents (Gashwiler 1967).

In this study, we focused on the effect of fungi on seed

Received 30 December 2005. Accepted 21 July 2006. Published on the NRC Research Press Web site at http://cjfr.nrc.ca on 11 May 2007.

H.K. Cho, S.G. Hong, and J.J. Kim. Department of Forest and Environmental Science, Konkuk University, Seoul 143-701, Korea. T. Miyamoto ${ }^{1}$ and K. Takahashi. Division of Environmental Resources, Graduate School of Agriculture, Hokkaido University, Sapporo 060-8589, Japan.

${ }^{1}$ Corresponding author (e-mail: tmiyamot@for.agr.hokudai.ac.jp). 
losses. Kurata (1949) proposed that escape from fungal damage is an important factor for natural forest regeneration. The distribution of fungal pathogens within the forest influences sites for tree regeneration. In the case of Tsuga canadensis (L.) Carr., seed germination in forest soil is significantly lower than on logs, and fungal pathogens in the soil may cause this decrease in seed viability (O'Hanlon-Manners and Kotanen 2004).

Soil-borne fungi may cause high mortality to seeds. Some fungi, such as Fusarium culmorum (W.G. Sm.) Sacc., Heterobasidiom annosum (Fr) Bref., Lirula macrospora (R. Hartig) Darker, Rhizoctonia solani Kühn, invade Abies spp. seeds (Mittal et al. 1990). Cheng (1989) reported that, in Japan, the pathogenic fungus Racodium therryanum Thuem. is an important factor inhibiting the natural regeneration of Picea jezoensis (Sieb. \& Zucc.) Carr. by seed germination. This fungus has high activity under the snow and is distributed in the litter layer where seed infections are most frequent. Racodium therryanum affects the seed stage of natural regeneration in the presence of litter and snow. Mount Halla has the largest population of A. koreana in Korea. Saplings occur mainly at the forest edge and are not found on the forest floor (Koh et al. 1996). The mechanism causing this difference in sapling distribution is unknown. Mount Halla is covered by snow in winter, and there is an accumulation of litter on the soil surface; thus, the risk of damage by seed pathogens during natural regeneration might be high at this site.

We examined the role of pathogens in the overwintering survival of A. koreana seeds in natural seedbeds on Mount Halla to identify factors affecting the pregermination stage. Specifically, we investigated: $(i)$ the occurrence of loss of germinability caused by seed pathogens in winter, (ii) the pathogenicity of fungi isolated from A. koreana seeds, and (iii) the effect of seedbed type and snow-cover period on the distribution of seed pathogens.

\section{Materials and methods}

\section{Study site and field experiment}

The study was conducted in natural A. koreana stands located at an elevation of $1700 \mathrm{~m}$ on Mount Halla, Jeju Island, Korea $\left(33^{\circ} 21^{\prime} \mathrm{N}, 126^{\circ} 31^{\prime} \mathrm{E}\right)$, where the mean annual precipitation is $1592 \mathrm{~mm}$ (Lee and Hong 1995) and the snow-cover period lasts from mid-November until mid-April (Jeju Regional Meterological Office 2005). The snow depth exceeds $1 \mathrm{~m}$ every year. The mean annual temperature is $4.2{ }^{\circ} \mathrm{C}$ (Lee and Hong 1995). The stands were dominated mostly by A. koreana and, rarely $(<1 \%)$, by Taxus cuspidata Sieb. \& Zucc., and they were surrounded by a dense population of the shrub Sasa quelpaertensis Nakai. Seedlings of A. koreana were not found within the forest stands but occurred near rocks (about $50 \mathrm{~cm}$ high) in the population of $S$. quelpaertensis.

In our study area, three types of seedbed were recognized: those covered with a dense population of $S$. quelpaertensis (hereafter, Sasa sites), those shaded by rocks (rock side), and those on the forest floor beneath the A. koreana canopy (forest floor).

Five experimental sites each were selected on south-facing and north-facing slopes (Fig. 1). Within each experimental area, a $30 \mathrm{~cm} \times 30 \mathrm{~cm}$ plot was set for each of the three types of seedbed. Thus, we had a $3 \times 2$ design, with $n=5$ for each treatment combination.

Seeds of A. koreana were collected from Mount Halla in 2001 by a seed dealer. Their viability by cutting test (Asakawa et al. 1981) was $72.6 \%$, and the germination rate of 150 -day stratified seeds was $48.8 \%$. Seeds were placed in $5 \mathrm{~cm} \times 5 \mathrm{~cm}$ nylon mesh bags with 150 seeds per bag. On 25-26 September 2003, these seed bags, containing dry and unstratified seeds, were placed on the seedbeds, one per plot. The seed bags were covered with plastic mesh to prevent rodent predation during the winter. The first snowfall occurred on 12 December 2003, at which time the forest soil was still unfrozen. Seed bags were retrieved on 910 April 2004. All bags were retrieved from under snow, and snow pack varied from $10 \mathrm{~cm}$ to $100 \mathrm{~cm}$ in depth at retrieval time.

The temperatures at the ground-snow interface during the snow-cover period were recorded with data loggers (StowAway, Onset Computer Corporation, Bourne, Mass.). We designated the snow-cover period as the total time during which the temperature did not fluctuate from $0{ }^{\circ} \mathrm{C}$.

\section{Analysis of germination capacity}

In the laboratory, the seeds from each seed bag were divided into two parts for analysis of germination capacity and seed pathogens. For analysis of germination capacity, seeds were placed on moist filter paper at $20{ }^{\circ} \mathrm{C}$ for 50 days, and the percent germination was recorded. Visible radicle protrusion was the criterion for germination. The seed number for the germination test varied (0-50) because of the restricted number of retrievable seeds in each experimental plot (Table 1).

\section{Fungal isolation and identification}

For the isolation of pathogens, seeds were washed in 0.01\% Tween 20 (ICN Biochemicals, Eschwege, Germany) for $1 \mathrm{~min}$. Seeds were then surface-sterilized in $70 \%$ ethanol for $1 \mathrm{~min}, 30 \%$ hydrogen peroxide for $2 \mathrm{~min}$, washed in distilled water for $1 \mathrm{~min}$, and then dried on sterile filter paper. Seeds were placed (three seeds per $9 \mathrm{~cm}$ Petri dish) on potato dextrose agar (PDA) and incubated at $5{ }^{\circ} \mathrm{C}$ for 4 weeks to isolate fungi adapted to low temperatures. We used 12-27 seeds for each of five replicates in the six treatment combinations (seedbed slope; Table 1). The remaining seeds from the same source (stored seeds) were stored in a refrigerator at $5{ }^{\circ} \mathrm{C}$ to isolate fungi adapted to low temperatures. Incubation at higher temperatures would lead to the situation that those fungi would be overgrown by mould or other fungi. To confirm whether they were infected by pathogens, the control seeds were treated in same manner as the experimental seeds. Fungi appearing on or around seeds were isolated and incubated at $20{ }^{\circ} \mathrm{C}$ on PDA.

Among the isolated fungi, we identified eight species that showed high rates of infection using morphological characteristics and (or) DNA analysis (Table 2). Racodium therryanum and Alternaria alternata (Fr.) Keissl. were identified using morphological characteristics (Cho et al. 2005; Domsch et al. 1993), whereas Sydowia polyspora (Bref. \& Tav.) Müller, Trichoderma asperellum Samuels, 
Fig. 1. Map of the study site.

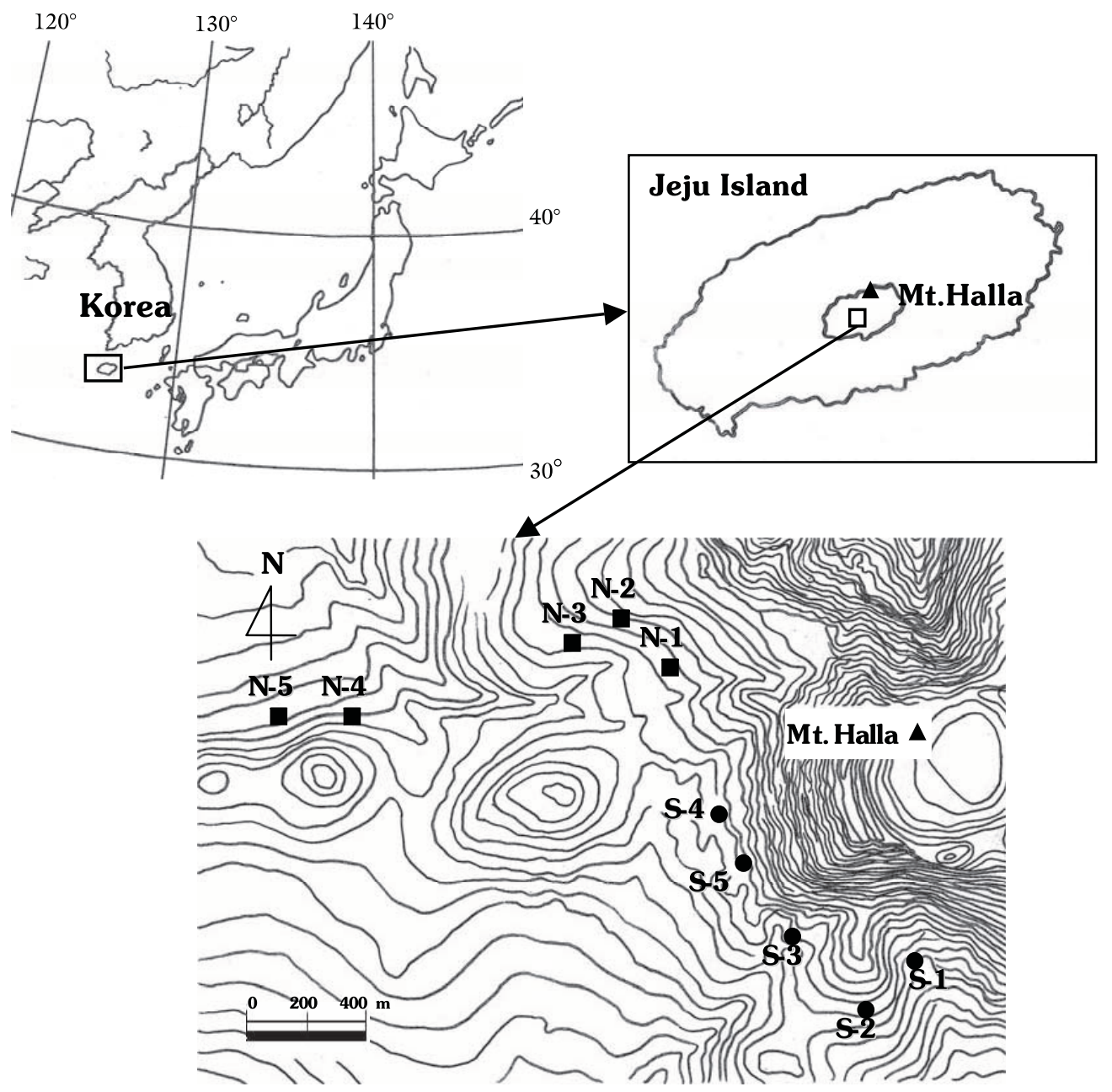

Table 1. Number of retrieved seeds Abies koreana seeds retrieved after overwintering on Mount Halla.

\begin{tabular}{|c|c|c|c|c|c|c|c|c|c|c|}
\hline & $\mathrm{S}-1^{a}$ & $\mathrm{~S}-2$ & $\mathrm{~S}-3$ & $\mathrm{~S}-4$ & $\mathrm{~S}-5$ & $\mathrm{~N}-1^{b}$ & $\mathrm{~N}-2$ & $\mathrm{~N}-3$ & $\mathrm{~N}-4$ & $\mathrm{~N}-5$ \\
\hline \multicolumn{11}{|c|}{ Total retrieval seeds ${ }^{c}$} \\
\hline Sasa site & 14 & 46 & 77 & 76 & 74 & 91 & 93 & 51 & 59 & 20 \\
\hline Rock side & 22 & 23 & 100 & 89 & 78 & 86 & 100 & 97 & 67 & 72 \\
\hline Forest floor & 65 & 17 & 34 & 42 & 81 & 130 & 125 & 85 & 100 & 110 \\
\hline \multicolumn{11}{|c|}{ Seeds for germination test } \\
\hline Sasa site & 0 & 0 & 50 & 50 & 50 & 47 & 47 & 23 & 40 & 0 \\
\hline Rock side & 0 & 0 & 50 & 49 & 49 & 49 & 46 & 50 & 40 & 45 \\
\hline Forest floor & 0 & 0 & 0 & 0 & 50 & 47 & 50 & 50 & 48 & 50 \\
\hline \multicolumn{11}{|c|}{ Seeds for fungi isolation } \\
\hline Sasa site & 14 & 27 & 26 & 24 & 23 & 27 & 27 & 27 & 27 & 12 \\
\hline Rock side & 17 & 12 & 27 & 27 & 24 & 27 & 27 & 27 & 27 & 27 \\
\hline Forest floor & 27 & 16 & 27 & 27 & 27 & 27 & 27 & 27 & 27 & 27 \\
\hline
\end{tabular}

Note: Rock sides were sites shaded by rocks; Sasa sites were covered with a dense population of Sasa quelpaertensis.

${ }^{a} \mathrm{~S}$, south-facing slope.

${ }^{b} \mathrm{~N}$, north-facing slope.

${ }^{c}$ Each experimental unit consisted of a bag containing 150 dried and unstratified seeds left to overwinter under natural conditions. 
Table 2. Eight fungal species in order of infection rate of Abies koreana seeds retrieved after overwintering in Mount Halla.

\begin{tabular}{|c|c|c|c|c|c|c|}
\hline $\begin{array}{l}\text { Infection } \\
\text { rate }(\%)\end{array}$ & Fungus & Identify & Identification basis & $\begin{array}{l}\text { Accession } \\
\text { No. }\end{array}$ & $\begin{array}{l}\text { Base } \\
\text { pairs }\end{array}$ & $\begin{array}{l}\text { Nucleotide } \\
\text { matches in } \\
\text { BLAST }(\%)\end{array}$ \\
\hline 19.9 & A & Racodium therryanum & Morphology & & & \\
\hline 14.4 & B & Sydowia polyspora & Morphology + ITS sequence & AF013228 & 554 & 99 \\
\hline 5.6 & $\mathrm{C}$ & Alternaria alternata & Morphology & & & \\
\hline 5.0 & $\mathrm{D}$ & Trichoderma asperellum & Morphology + ITS sequence & AJ230680 & 561 & 99 \\
\hline 5.5 & $\mathrm{E}$ & Arthrinium sp. & ITS sequence & AJ279479 & 540 & 100 \\
\hline 4.9 & $\mathrm{~F}$ & Unidentified sterile fungus & ITS sequence & AY880947 & 168 & 98 \\
\hline 3.8 & G & Neonectria ramulariae & ITS sequence & AJ279446 & 522 & 100 \\
\hline 3.7 & $\mathrm{H}$ & Epacris microphylla & ITS sequence & AY268201 & 479 & 100 \\
\hline
\end{tabular}

Note: The identification basis indicates how each species was identified, and the accession number indicates the best match to a known species in a BLAST search of internal transcribed spacer (ITS) sequence data.

Arthrinium sp., an unidentified sterile fungus, Neonectria ramulariae Wollenw., and Epacris microphylla $\mathrm{R}$. Br. were identified using the ribosomal DNA (rDNA) of representative isolates.

Fungal DNA was extracted from a piece (about $5 \mathrm{~mm} \times$ $5 \mathrm{~mm} \times 1 \mathrm{~mm}$ ) of isolated fungal mycelium grown on PDA. We used Isoplant (Nippon Gene, Tokyo, Japan) following the manufacturer's guidelines. Extracted DNA was dissolved in $50 \mu \mathrm{L}$ of TE buffer (Nippon Gene) and $1 \mu \mathrm{L}$ of the RNaseA. Because the internal transcribed spacer (ITS) region of nuclear rDNA has highly conserved DNA sequences, we used it as the amplification region. We employed universal primers for fungal ITS1-F and ITS4 (White et al. 1990). PuRe Taq Ready-To-Go PCR Beads (Nippon Gene, Toyama, Japan), and the GeneAmp PCR System 2400 (Perkin-Elmer, Fremont, Calif.) were used. The samples were run at an initial denaturation for $30 \mathrm{~s}$ at $94{ }^{\circ} \mathrm{C}$, followed by 40 cycles of denaturation for $1 \mathrm{~min}$ at $94{ }^{\circ} \mathrm{C}$, annealing for $1 \mathrm{~min}$ at $50{ }^{\circ} \mathrm{C}$, and extension for $2 \mathrm{~min}$ at $72{ }^{\circ} \mathrm{C}$ for $S$. polyspora, Arthrinium sp., and E. microphylla. The samples were run at an initial denaturation for $30 \mathrm{~s}$ at $94{ }^{\circ} \mathrm{C}$ followed by 30 cycles of denaturation for $1 \mathrm{~min}$ at $94{ }^{\circ} \mathrm{C}$, annealing for $1 \mathrm{~min}$ at $50{ }^{\circ} \mathrm{C}$, and extension for $2 \mathrm{~min}$ at $72{ }^{\circ} \mathrm{C}$ for the unidentified sterile fungus. The samples were run at an initial denaturation for $3 \mathrm{~min}$ at $94{ }^{\circ} \mathrm{C}$, followed by 35 cycles of denaturation for $1 \mathrm{~min}$ at $94{ }^{\circ} \mathrm{C}$, annealing for $1 \mathrm{~min}$ at $50{ }^{\circ} \mathrm{C}$, extension for $3 \mathrm{~min}$ at $72{ }^{\circ} \mathrm{C}$, and final extension for $10 \mathrm{~min}$ at $72{ }^{\circ} \mathrm{C}$ for $T$. asperellum and $N$. ramulariae. Sequencing was performed by a Biosystems 3730xl DNA Analyzer (BIO MATRIX Research, Chiba, Japan). The rDNA sequences obtained were compared with data sets in GenBank (DNA Data Bank of Japan 2005) using basic local alignment search tool (BLAST) analysis.

\section{Pathogenicity of fungi}

The pathogenicity of the eight fungi was determined by the soil over agar culture inoculation method (Watanabe 1988). Two strains of each fungus were selected from plots whenever possible and examined. PDA cultures were prepared by growing each fungus at $23{ }^{\circ} \mathrm{C}$ for 7 days. Soil that had been seived through a $0.5-1.0 \mathrm{~mm}$ mesh screen and autoclaved (peatmoss:vermiculite $=1: 9$, w/w) was placed $2 \mathrm{~mm}$ deep over PDA and watered. Seeds were placed
(50 seeds per Petri dish) (Asakawa et al. 1981) on the soil (controls contained only soil and PDA) and incubated at $0{ }^{\circ} \mathrm{C}$ and $23{ }^{\circ} \mathrm{C}$ with five replications. Seed viability was assessed with the tetrazolium test (Asakawa et al. 1981) (except for empty seeds) after 30 and 100 days.

\section{Data analysis}

Germination rate of retrieved seeds was calculated as the proportion of germinated seeds to total seeds. Data for the germination rate by seedbed type was subjected to one-way analyses of variance (ANOVA) followed by Tukey's test.

Infection rate of retrieved seeds was calculated as the percentage of seeds infected by each pathogenic fungus to total seeds within a replicate. Data for seed infection rate and loss of germination ability were arcsine transformed and subjected to two-way ANOVAs followed by Tukey's test.

The relationship between the seed germination rate and the infection rate was examined by correlation analysis with Pearson's correlation coefficient. The relationship between snow-cover period and the infection rate was also examined by correlation analysis with Pearson's correlation coefficient.

Loss of germination ability was calculated as the proportion of nonviable seeds to total seeds, excluding empty seeds. For each fungus, data on loss of germination ability attributable to infection were arcsine transformed, followed by a nested ANOVA and Tukey's test.

All statistical analyses were conducted using SPSS version 9.0 J (SPSS, Chicago, Illinois).

\section{Results}

\section{Germination rate of retrieved seeds}

We collected 14-130 seeds depending on plots (Table 1). None of the seeds had germinated. Seed germination rates at recovery varied by seedbed type. Germination rate was significantly lower on the forest floor than in the Sasa sites (Fig. 2). The effect of slope direction was not analyzed because very small numbers of seeds were retrieved from south-facing slope.

\section{Infection rate of retrieved seeds}

Isolation from retrieved seeds yielded 20 types of fungus. No fungal growth was observed on seeds stored in the re- 
Fig. 2. Effects of seedbed type on germination rate of Abies koreana seeds. Error bars are SEs. Values with different letters are significantly different $(p<0.05)$.

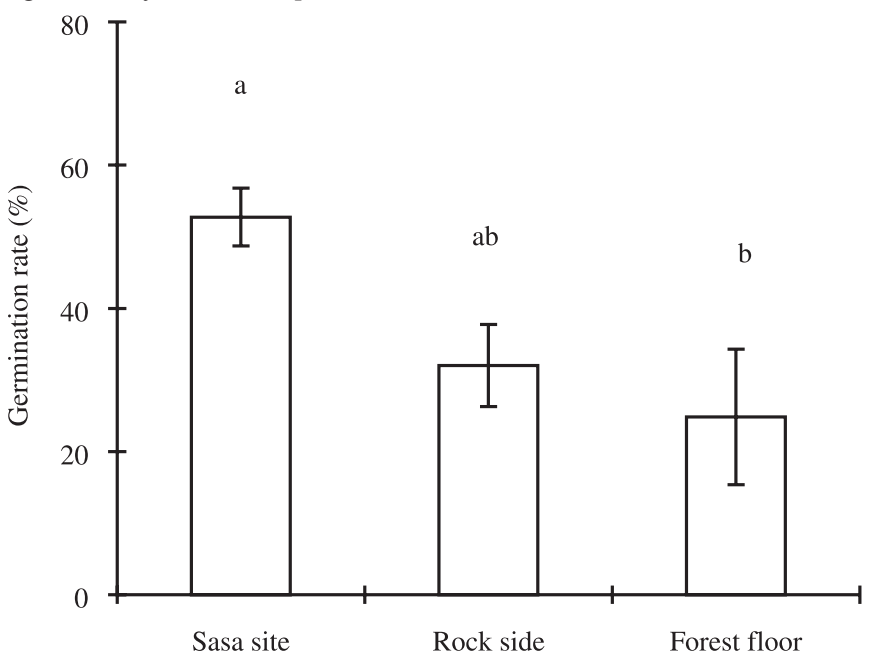

frigerator. Among other species, R. therryanum, S. polyspora, A. alternata, T. asperellum, Arthrinium sp., an unidentified sterile fungus, $N$. ramulariae, and E. microphylla were isolated from retrieved seeds. Overall infection rates of $R$. therryanum and $S$. polyspora were $19.9 \%$ and $14.4 \%$, respectively, whereas the other species had infection rates of less than 5\% (Table 2). Racodium therryanum had the lowest infection rate in the Sasa sites (mean: south-facing slopes (S), 1.5\%; north-facing slopes (N), 3.9\%) and the highest rates on the forest floor (mean: S, 40.8\%; N, 25.9\%). These differences were significant (Table 3; Fig. 3). In contrast, $S$. polyspora, which had the second highest infection rate, was most infectious in the Sasa sites (mean: S, $27.2 \% ; \mathrm{N}, 30.9 \%$ ) and least on the forest floor (mean: $\mathrm{S}$, $7.9 \% ; \mathrm{N}, 1.5 \%)$. These differences were also significant (Table 3; Fig. 3). We observed no significant difference in infection rates between south-facing and north-facing slopes (Table 3).

\section{Relationship between seed infection rate and seed germination rate}

Figure 4 shows the relationship between the seed infection rate for each fungus and the seed germination rate. The infection rate of $R$. therryanum showed a negative correlation with seed germination rate $(r=-0.648, p<0.01)$. In contrast, the infection rate of $S$. polyspora was positively correlated with seed germination rate $(r=0.527, p<0.05)$. No significant correlation was found between the seed infection rate by other fungi and the seed germination rate.

\section{Relationship between seed infection rate and snow-cover period}

Figure 5 shows the relationship between the seed infection rate by each fungus and the snow-cover period. The infection rate of $R$. therryanum showed a positive correlation with snow-cover period $(r=0.457, p<0.05)$. In contrast, the infection rate of $S$. polyspora had a negative correlation with snow-cover period $(r=-0.473, p<0.05)$. No signifi-
Table 3. Results of two-way ANOVA showing the effects of slope direction and seedbed types on the infection rate of Abies koreana seeds by eight soil-borne fungi.

\begin{tabular}{|c|c|c|c|c|}
\hline Component & MS & df & $F$ & $p$ \\
\hline \multicolumn{5}{|l|}{ Racodium therryanum } \\
\hline Slope direction & 271.081 & 1 & 0.928 & 0.345 \\
\hline Seedbed type & 3488.910 & 2 & 5.971 & 0.008 \\
\hline Slope $\times$ seedbed type & 639.035 & 2 & 1.094 & 0.351 \\
\hline Error & 7012.260 & 24 & & \\
\hline \multicolumn{5}{|l|}{ Sydowia polyspora } \\
\hline Slope direction & 12.160 & 1 & 0.133 & 0.719 \\
\hline Seedbed type & 2798.728 & 2 & 15.301 & $<0.001$ \\
\hline Slope $\times$ seedbed type & 383.026 & 2 & 2.094 & 0.145 \\
\hline Error & 2194.885 & 24 & & \\
\hline \multicolumn{5}{|l|}{ Altenaria alternata } \\
\hline Slope direction & 20.271 & 1 & 0.251 & 0.621 \\
\hline Seedbed type & 786.947 & 2 & 4.874 & 0.017 \\
\hline Slope $\times$ seedbed type & 316.765 & 2 & 1.962 & 0.163 \\
\hline Error & 1937.678 & 24 & & \\
\hline \multicolumn{5}{|c|}{ Trichoderma asperellum } \\
\hline Slope direction & 57.242 & 1 & 0.549 & 0.485 \\
\hline Seedbed type & 155.580 & 2 & 0.746 & 0.466 \\
\hline Slope $\times$ seedbed type & 115.795 & 2 & 0.556 & 0.581 \\
\hline Error & 2501.032 & 24 & & \\
\hline \multicolumn{5}{|l|}{ Arthrinium sp. } \\
\hline Slope direction & 66.842 & 1 & 0.475 & 0.498 \\
\hline Seedbed type & 28.731 & 2 & 0.102 & 0.903 \\
\hline Slope $\times$ seedbed type & 118.464 & 2 & 0.421 & 0.661 \\
\hline Error & 3380.430 & 24 & & \\
\hline \multicolumn{5}{|c|}{ Unidentified (sterile fungi) } \\
\hline Slope direction & 65.890 & 1 & 0.581 & 0.453 \\
\hline Seedbed type & 291.907 & 2 & 1.286 & 0.295 \\
\hline Slope $\times$ seedbed type & 87.555 & 2 & 0.386 & 0.684 \\
\hline Error & 2723.264 & 24 & & \\
\hline \multicolumn{5}{|l|}{ Neonectria ramulariae } \\
\hline Slope direction & 55.108 & 1 & 0.985 & 0.331 \\
\hline Seedbed type & 174.025 & 2 & 1.555 & 0.232 \\
\hline Slope $\times$ seedbed type & 346.277 & 2 & 3.093 & 0.064 \\
\hline Error & 1343.297 & 24 & & \\
\hline \multicolumn{5}{|l|}{ Epacris microphylla } \\
\hline Slope direction & 211.099 & 1 & 2.838 & 0.105 \\
\hline Seedbed type & 173.448 & 2 & 1.166 & 0.329 \\
\hline Slope $\times$ seedbed type & 71.255 & 2 & 0.479 & 0.625 \\
\hline Error & 1785.492 & 24 & & \\
\hline
\end{tabular}

Note: $* p<0.05 ; * * p<0.01 ; * * * p<0.001$.

cant correlations were observed between the infection rates of other fungi and snow-cover period.

\section{Pathogenicity of fungi isolated from A. koreana seeds}

The loss of seed germination ability varied with pathogenic fungi and temperature (Fig. 6). The loss of seed germination ability increased with the duration of infection, except in the case of A. alternata. A particularly marked significant difference occurred between the two times in losses caused by $R$. therryanum, which had the highest infection rate in the field. The mean loss at $0{ }^{\circ} \mathrm{C}$ caused by $R$. therryanum was 
Fig. 3. Infections of Abies koreana seeds by each pathogenic fungus in each slope and seedbed type. (A) Racodium therryanum; (B) Sydowia polyspora; (C) Alternaria alternata; (D) Trichoderma asperellum; (E) Arthrinium sp.; (F) unidentified sterile fungus; (G) Neonectria ramulariae; $(\mathrm{H})$ Epacris microphylla (open bars, south-facing slope; shaded bars, north-facing slope) $(n=5)$. Error bars are SEs. Values with different letters are significantly different $(p<0.05)$.
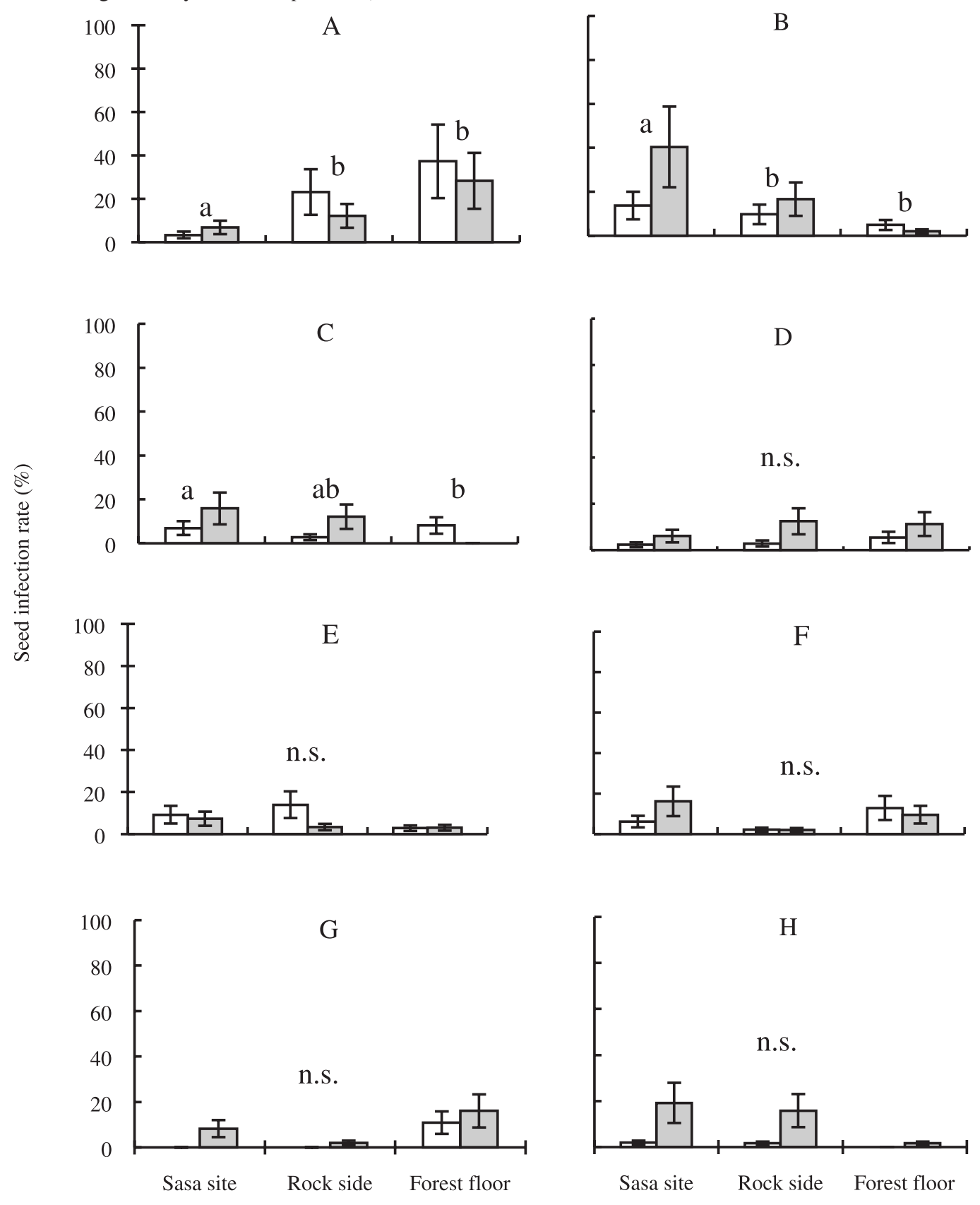

$100 \%$ after 100 days in both strains. In S. polyspora, the loss of seed germination ability was below $11 \%$.

\section{Discussion}

Inhibition of germination by seed pathogens

The loss of seed viability in soil often represents a substantial proportion of total plant mortality (Cavers 1983). Processes that influence seed survivorship in soil clearly have important consequences for plant establishment (Kozlowski 1971). Fungi play an important role in seed survivorship in soil (Crist and Friese 1993; Leishman et al.
2000; Blaney and Kotanen 2001), and many fungi inhibit seed germination (Dinoor and Eshed 1984). The fungus Geniculodendron pyriforme Salt attacks seeds of Picea engelmannii Parry ex Engelm. and causes germination failure in the United States (Wicklow-Howard and Skujins 1980). In Canada, G. pyriforme has been isolated from Pinus resinosa Ait. seeds that failed to germinate (Epners 1964). Zhong and van der Kamp (1999) examined the viability of overwintered $P$. engelmannii and Abies lasiocarpa (Hook.) Nutt. seeds. Seed viability at recovery was low, and seed pathogens appeared to cause major losses in high-elevation forests of interior British Columbia. 
Fig. 4. Relationship between overwintering germination and infection rates of Abies koreana seeds by each pathogenic fungus. (A) Racodium therryanum; (B) Sydowia polyspora; (C) Alternaria alternata; (D) Trichoderma asperellum; (E) Arthrinium sp.; (F) unidentified sterile fungus; (G) Neonectria ramulariae; $(\mathrm{H})$ Epacris microphylla $(n=21)$. The number of dots indicates the number of seeds for germination test.
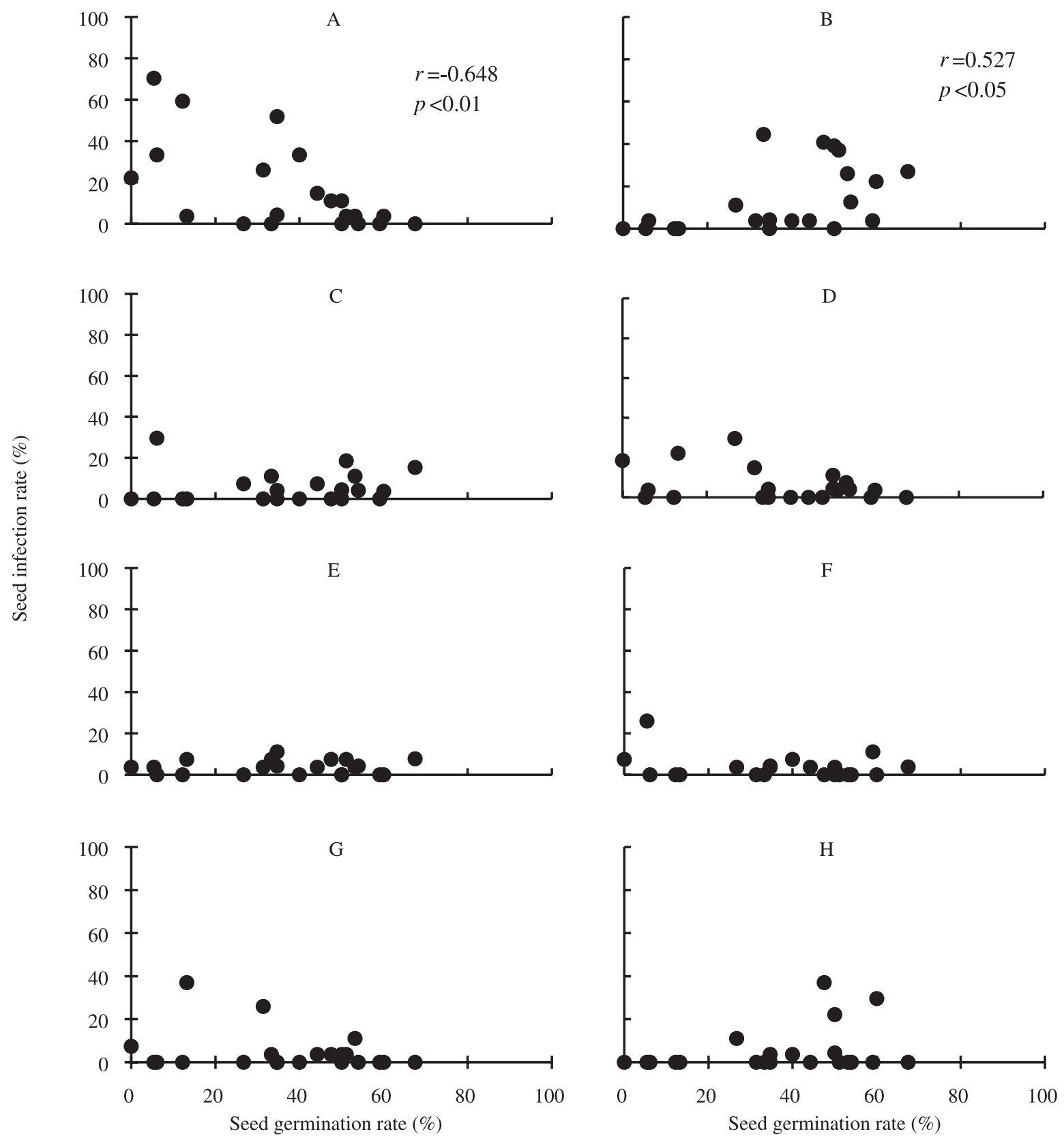

In our study, the infection rate by $R$. therryanum was highest in seeds retrieved from the field. In the in vitro pathogenicity test, $R$. therryanum caused the greatest loss in germination ability in $A$. koreana seeds at $0{ }^{\circ} \mathrm{C}$ after 100 days. Therefore, $R$. therryanum may cause the most serious disease in A. koreana seeds overwintering on Mount Halla. This is further supported by the negative correlation between the infection rate of $R$. therryanum and the seed germination rate.

Racodium therryanum is the casual agent of snow blight and has been considered a strong inhibitor of natural regen- eration of conifer stands in Japan (Sakamoto and Miyamoto 2005). This pathogen infects seeds of Abies sachalinensis (F. Schmidt.) Mast. (Hayashi and Endo 1975), P. jezoensis (Cheng and Igarashi 1987), Picea glehnii (F. Schmidt.) Mast. (Cheng and Igarashi 1990), and Larix kaempferi (Lamb.) Carr. (Igarashi and Cheng 1988). In addition to conifer seeds, $R$. therryanum also attacks seeds of Betula maximowicziana Regel., resulting in a decreased germination rate (Kishida et al. 1985). Although seed rot caused by forest pathogens was previously unknown in Korea, our study suggests that damage by $R$. therryanum may be a sig- 
Fig. 5. Relationship between snow-cover period and infection of Abies koreana seeds by each pathogenic fungus. (A) Racodium therryanum; (B) Sydowia polyspora; (C) Alternaria alternata; (D) Trichoderma asperellum; (E) Arthrinium sp.; F) unidentified sterile fungus; (G) Neonectria ramulariae; $(\mathrm{H})$ Epacris microphylla $(n=28)$. The number of dots indicates the number of the sites where the snow-cover period was measured using data loggers. The snow-cover period was designated as the total time during which the temperature did not fluctuate from $0{ }^{\circ} \mathrm{C}$.
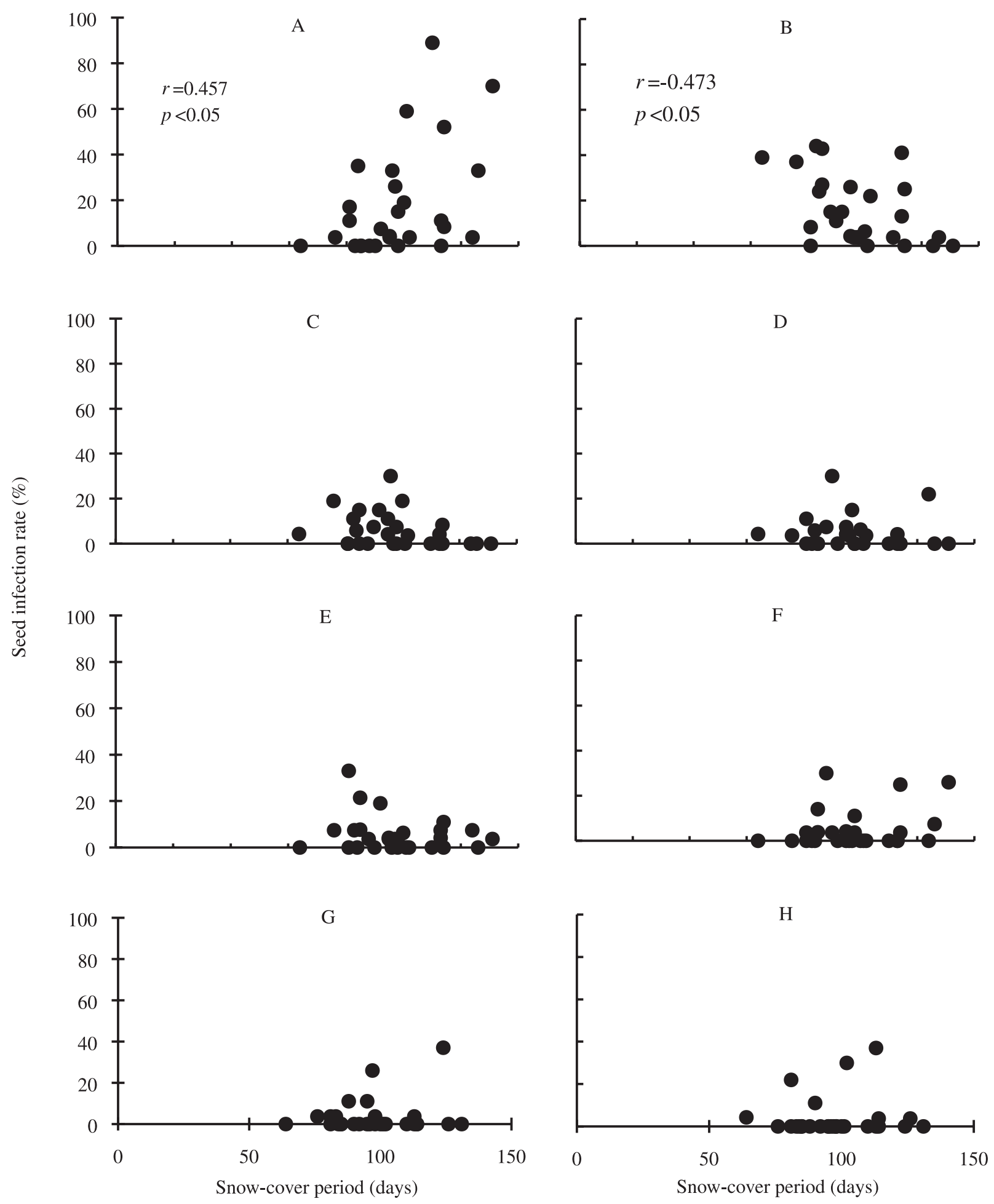

nificant inhibitory factor for the natural regeneration of A. koreana from the seed stage.

Sydowia polyspora causes sclerophoma dieback of Pseudotsuga menziesii (American Phytopathological Society.
2005) and phomopsis twig blight of juniper (Pataky 2005). The second highest infection rate among the fungi isolated in our study was that of $S$. polyspora (14.4\%) (Table 2). However, the reductions in the seed germination rate were 
Fig. 6. Loss of germination ability by Abies koreana seeds caused by each pathogenic fungus. A, Racodium therryanum; B, Sydowia polyspora; C, Alternaria alternata; D, Trichoderma asperellum; E, Arthrinium sp.; F, unidentified sterile fungus; G, Neonectria ramulariae; H, Epacris microphylla; I, control. There were two strains analyzed per species $(n=5)$. Values with different letters are significantly different $(p<0.05)$.
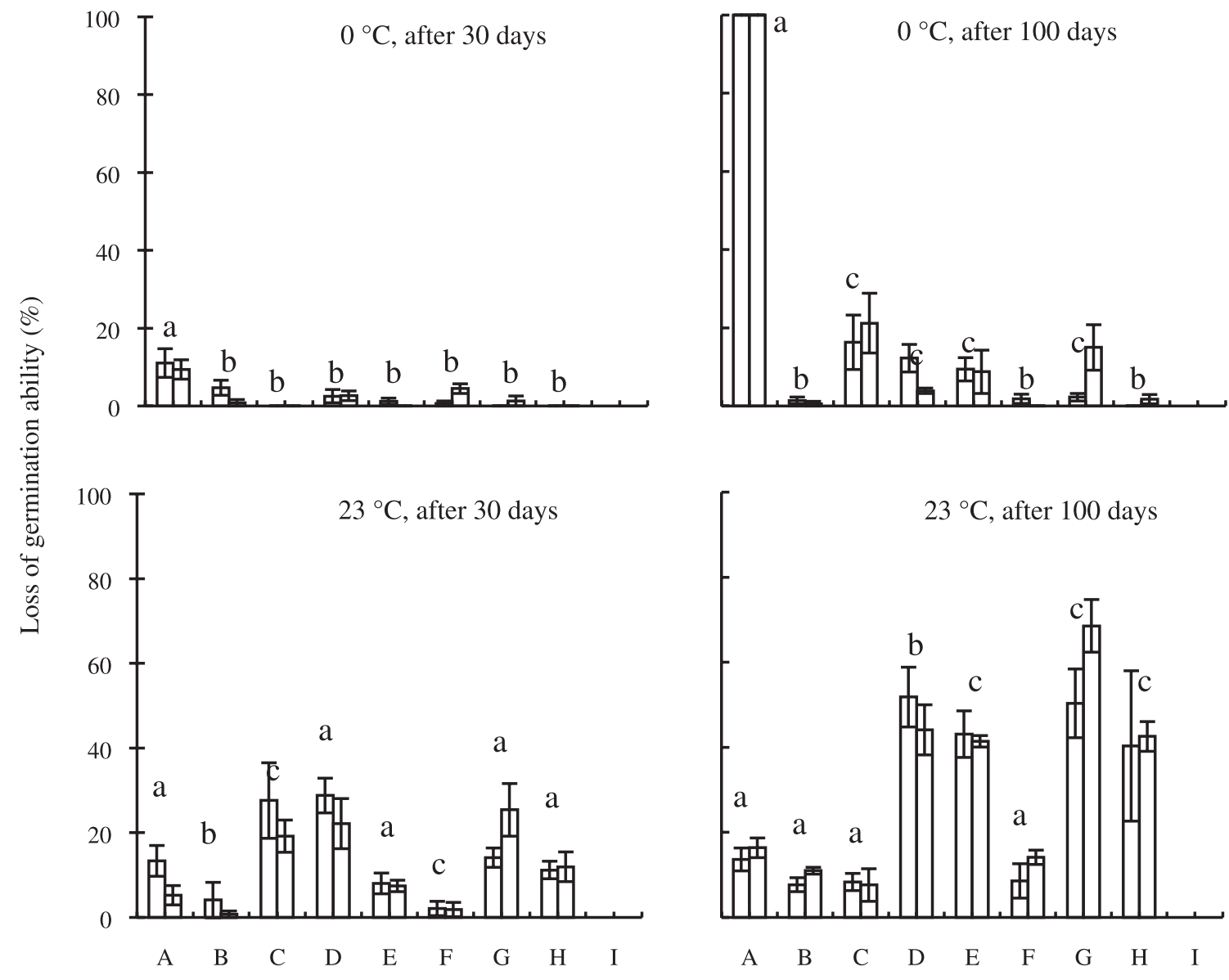

low in vitro (Fig. 6). This may indicate that $S$. polyspora is not an important cause of seed germination loss.

Fruit rots due to Alternaria alternata have been reported in citrus, apple, and pear. Hemiparasitic effects of A. alternata include a yellowing of jute cotyledons, chlorosis in young apple leaves, and albinism in citrus seedlings and numerous other plants (Domsch et al. 1993). In conifers, A. alternata attacks the seeds of Pinus densiflora Sieb. \& Zucc. and Cryptomeria japonica (L.f.) D. Don (Watanabe 2002). In our study, this fungus caused about a $20 \%$ loss of germination ability in A. koreana in vitro (Fig. 6).

The following fungi may not cause high losses of germination ability in A. koreana seeds in winter: T. asperellum, Arthrinium sp., an unidentified fungus, $N$. ramulariae, and E. microphylla. (The last two species were identified with $100 \%$ nucleotide matches in BLAST searches but did not form spores.) For all of these fungi, the infection rate was $\leq 5 \%$ (Table 2). We found that Trichoderma sp., N. ramulariae, and E. microphylla had high pathogenicity at $23{ }^{\circ} \mathrm{C}$ after 100 days, but not at $0{ }^{\circ} \mathrm{C}$. For this reason, we suggest that these fungi may not cause high losses of germination ability in A. koreana seeds in winter.

In our study, we recovered low numbers of seeds from 150 seeds placed in each bag (Table 1). In other studies, removed seeds have been consumed by seed predators, such as ants, rodents, birds, and beetles (Vander Wall et al. 2005). This indicates a high rate of loss and, potentially, may represent a major problem, and losses to fungi may have been overestimated (Van Mourik et al. 2005). For understanding of the factors that affect seed germination and initial seedling survival of $A$. koreana, we need to investigate the initial step of seed fate.

\section{Relationship between fungal damage and seedbed type}

In subalpine forests dominated by evergreen conifers such as Abies, Picea, and Tsuga, tree seedlings and saplings appear on fallen logs (Kupferschmid and Bugmann 2005; Nakagawa et al. 2001; Narukawa and Yamamoto 2001). The importance of fallen logs as recruitment sites for seedlings can be explained partly by the refuge they provide from pathogenic soil fungi (O'Hanlon-Manners and Kotanen 2004).

Cheng (1989) examined the occurrence of the seed rot caused by $R$. therryanum in different forest floor types and in the different layers of soil. Among the floor types, $R$. therryanum caused fewer seed infections in moss and Sasa-litter type floors, whereas numerous infections occurred in coniferous-litter and broadleaved-litter type floors. The author also reported that the greatest infection rate occurred in the surface organic layer $\left(\mathrm{A}_{0}\right.$ layer $)$ of the soil and 
that seeds can survive in mineral soil (where the $\mathrm{A}_{0}$ layer has been removed). Disease was found to occur on all seedbed types except decayed fallen logs, which proved to be the only seedbed type free of $R$. therryanum infestation.

Zhong and van der Kamp (1999) examined seed viability and frequency of fungal isolation for seeds overwintering in various types of natural and disturbed forest floor seedbeds: litter-removed forest floor, moss-removed forest floor, mineral soil (all organic material removed), and organic material-mixed forest floor. They showed that seed pathogens appear to cause a major loss of seeds and seedlings, which may explain both the common occurrence of regeneration on nurse $\operatorname{logs}$ and the requirement of mineral soil seed beds for adequate regeneration.

In our study, the seed germination rate at recovery varied with the seedbed type. Germination rate was lower on the forest floor than in Sasa sites. The infection rate by each fungus also varied with seedbed type. In particular, the infection rate by $R$. therryanum was higher on the forest floor than in Sasa sites. This result suggests that the difference in the ability to germinate in different seedbed types was affected by the infection rate by $R$. therryanum.

Racodium therryanum was originally described by De Thuemen (1880) on twigs of Picea abies. Later on, it was redescribed by Saccardo and Sydow (1899) and was discussed as one of the major snow blight disease to conifer seedlings by Sato et al. (1960). Racodium therryanum was mostly distributed on the forest floor, which accounts for the pronounced loss of germination ability at these sites. Sanada et al. (1984) reported that $R$. therryanum favors growth on leaves rich in minerals (such as $\mathrm{N}, \mathrm{P}$, and $\mathrm{Ca}$ ), which suggests that increases in nutrients may inevitably lead to the risk of invasion by $R$. therryanum. Cheng (1989) also showed that $R$. therryanum occurs mainly in the surface organic layer $\left(\mathrm{A}_{0}\right.$ layer) of the soil. On the soil surface of the forest floor in $A$. koreana stands, there was an accumulation of litter, which may generate abundant nutrients for $R$. therryanum. Although more investigation is needed, this may be a likely explanation for the lack of regeneration by A. koreana on the forest floor.

Sasa-dominated sites are unfavorable for conifer regeneration (Cheng 1989). In our study, the infection rate by $R$. therryanum, which can cause serious damage, was low in Sasa sites. In contrast, the infection rate by $S$. polyspora, which causes no damage, was high in Sasa sites. This suggests that there may be other unknown factors inhibiting the regeneration of A. koreana.

Because the emergence of $A$. koreana seedlings in the field was observed near rocks, these were considered favorable sites for regeneration by A. koreana. Our results for sites adjacent to rocks indicated characteristics intermediate between those of the forest floor and Sasa sites. Thus, rock sides were not the best sites for avoiding fungal damage. There are likely other unknown factors of these sites that influence the emergence of A. koreana seedlings. More research is needed.

\section{Relationship between fungal damage and snow-cover period}

Ecological characteristics of $R$. therryanum have a close relation with the existence of snow cover. The temperature under the snow is about $0{ }^{\circ} \mathrm{C}$, and humidity is about $100 \%$; these conditions are within the range for the development of disease caused by $R$. therryanum $\left(0-10{ }^{\circ} \mathrm{C}\right.$ and $92 \%-100 \%$; Cheng 1989). Cheng (1989) also reported that seeds of Picea jezoensis lose their viability within 4 months, due to infestation by $R$. therryanum at $0{ }^{\circ} \mathrm{C}$ and saturating moisture conditions. In most of the forested districts in Hokkaido, Japan, the forest floor is commonly under snow cover for more than 4 months during the winter. In such areas, $P$. jezoensis regeneration from seed seems impossible (Cheng 1989). For seeds of Abies sachalinensis, one of the most important factors inhibiting germination is an attack by $R$. therryanum under snow cover, and the activity of this fungus is accelerated in unfrozen soils of natural stands (Hayashi and Endo 1975). Hence, attacks by $R$. therryanum under field conditions usually occur beneath the snow.

Our study also showed that the infection rate of $R$. therryanum was negatively correlated with the germination rate. The infection rate increased with the duration of the snowcover period. Furthermore, the pathogenicity of $R$. therryanum was very strong at $0{ }^{\circ} \mathrm{C}$ after 100 days (which is concordant with observations of Cho et al. (2005) that $R$. therryanum is vigorous at $0{ }^{\circ} \mathrm{C}$ ). In our study, the snowcover period was 64-131 days (mean 98 days). This condition is suitable for the pathogen. This duration of snow cover likely promotes fungal damage to A. koreana seeds.

\section{Forest management for natural regeneration of A. koreana}

In Hokkaido, where damage caused by $R$. therryanum is a serious issue, removal of the $\mathrm{A}_{0}$ layer with raker-equipped bulldozers has been undertaken as a method of controlling the disease and promoting the natural regeneration of conifer seedlings (Hayashi and Endo 1975; Cheng et al. 1990). Cheng and Igarashi (1990) performed seed treatment (with tetramethylthiuram disulfide, TMTD) tests on naturally infested forest floors in winter. The germination rate of treated seeds was $51 \%$, whereas no germination was observed in untreated seeds. A combination of seed treatment and sanitizing the soil with pentachloronitrobenzene (PCNB, $20 \mathrm{~g} \cdot \mathrm{m}^{-2}$ ) was also effective (Hayashi and Endo 1975).

Because $A$. koreana stands are very dense (1560 trees $\left.\cdot \mathrm{ha}^{-1}\right)$, removing the $\mathrm{A}_{0}$ layer is almost impossible. Therefore, seed treatment by chemical fungicides is required. However, forest-management procedures, including fungicide treatment, must be planned carefully. Although further studies will be needed to find a method for avoiding fungal damage, the results of our study provide a basis for elucidating the natural regeneration mechanism of A. koreana.

\section{Acknowledgments}

This study is a part of the doctoral thesis of the senior author. This work was supported by a joint research project under the KOSEF-JSPS Cooperative Program F01-2003000-00124-0 from the Korea Science and Engineering Foundation and the Japan-Korea Basic Scientific Cooperation Program of the Japan Society for the Promotion of Science. We thank the staff of the Hallasan National Park Management Office and Mr. DongWon Kim, a graduate student of Konkuk University, who supported the field experiments in Korea. 


\section{References}

American Phytopathological Society. 2005. Common names of plant diseases: diseases of Douglas-fir. Available from http://www. apsnet.org/online/commom/names/dougfir [Accessed 3 June 2005.]

Asakawa, S., Katsuta, M., and Yokoyama, T. 1981. Seeds of woody plants in Japan. Gymnospermae. Japan Forest Tree Breeding Association. Tokyo, Japan.

Baillie, J.E.M., Hilton-Taylor, C., and Stuart, S.N.(Editors). 2004. 2004 IUCN red list of threatened species. Available from http:// www.iucnredlist.org [Accessed 30 December 2005.]

Blaney, C.S., and Kotanen, P.M. 2001. Effects of fungal pathogens on seeds of native and exotic plants: a test using congeneric pairs. J. Appl. Ecol. 38: 1104-1113. doi:10.1046/j.1365-2664. 2001.00663.x.

Cavers, P.B. 1983. Seed demography. Can. J. Bot. 61: 3578-3590.

Cheng, D. 1989. Studies on Racodium therryanum-caused in-soil seed rot with special reference to its impact on natural regeneration of Yezo spruce. Res. Bull. Exp. For. Fac. Agric. Hokkaido Univ. 46: 529-575. [In Japanese with English summary.]

Cheng, D., and Igarashi, T. 1987. Fungi associated with natural regeneration of Picea jezoensis Carr. in seed stage - their distribution on forest floors and pathogenicity to the seeds. Res. Bull. Exp. For. Fac. Agric. Hokkaido Univ. 44: 175-188.

Cheng, D., and Igarashi, T. 1990. Comparison of susceptibility to Racodium therryanum infection of seeds and seedlings of four coniferous species. Res. Bull. Exp. For. Fac. Agric. Hokkaido Univ. 47: 125-136. [In Japanese with English summary.]

Cho, H.K., Miyamoto, T., Takahashi, K., Kim, D.S., Hong, S.G., and Kim, J.J. 2005. First report on Racodium therryanum associated with seed infection of Abies koreana in Korea. Plant Pathol. J. 21: 297-300.

Crist, T.O., and Friese, C.F. 1993. The impact of fungi on soil seeds: implications for plants and granivores in a semiarid shrub-steppe. Ecology, 74: 2231-2239. doi:10.2307/1939576.

De Thuemen, F. 1880. Quelques espèces nouvelles de champignons de la France. Rev. Mycol. (Paris), 2: 86-87.

Dinoor, A., and Eshed, N. 1984. The role and importance of pathogens in natural plant communities. Annu. Rev. Phytopathol. 22: 443-466. doi:10.1146/annurev.py.22.090184.002303.

DNA Data Bank of Japan. 2005. Citing online sources. Available from http://www.ddbj.nig.ac.jp. [Accessed 30 December 2005.]

Domsch, K.H., Gams, W., and Anderson, T.-H. 1993. Compendium of soil fungi Vol.1. IHW-Verlag.

Epners, Z. 1964. A new psychrophilic fungus causing germination failure of conifer seeds. Can. J. Bot. 42: 1589-1604.

Gashwiler, J.S. 1967. Conifer seed survival in a western Oregon clearcut. Ecology, 48: 431-438. doi:10.2307/1932678.

Hayashi, K., and Endo, K. 1975. Effect of soil fungi and drought on the germination of todo-fir seed. Bull. Gov. For. Exp. Stn. 274: 1-22. [In Japanese with English summary.]

Igarashi, T., and Cheng, D. 1988. Fungal damage caused by Racodium therryanum to regeneration of Japanese larch by natural seedling. Res. Bull. Exp. For. Fac. Agric. Hokkaido Univ. 45: 213-219.

Jeju Regional Meterological Office. 2005. Citing online sources. Available from http://jeju.kma.go.kr. [Accessed 1 December 2005.]

Kim, G.T., Choo, G.C., and Baek, G.J. 1998. Studies on the structure of forest community in subalpine zone of Mt. Halla-Abies koreana forest. J. Kor. For. Soc. 87: 366-371. [In Korean with English summary.]

Kishida, A., Endo, K., and Sanada, M. 1985. The effects of the fungi causing seedling disease on natural regeneration (IV): rela- tionship between the germination of seeds and fungal disease on the soils under various kinds of trees. Trans. Meet. Hokkaido Br. Jpn. For. Soc. 34: 106-107. [In Japanese.]

Koh, J.G., Kim, D.S., Koh, S.C., and Kim, M.H. 1996. Dynamics of Abies koreana forest on Mt. Halla. J. Cheju. Studies, 13: 223-241. [In Korean.]

Kozlowski, K.K. 1971. Seed germination and seedling development. In Growth and development of trees. Vol. I. Seed germination, ontogeny, and shoot growth. Academic Press, New York and London. pp.41-93.

Kupferschmid, A.D., and Bugmann, H. 2005. Effect of microsites, logs and ungulate browsing on Picea abies regeneration in a mountain forest. For. Ecol. Manage. 205: 251-265. doi:10.1016/ j.foreco.2004.10.008.

Kurata, M. 1949. On the outline of the escape theory. J. Jpn For. Soc. 32: 32-34. [In Japanese.]

Lawrence, W.H., and Rediske, J.H. 1962. Fate of sown Douglas-fir seed. For. Sci. 8: 210-218.

Lee, Y.W., and Hong, S.C. 1995. Ecological studies on the vegetational characteristics of the Abies koreana forest. J. Kor. For. Soc. 84: 247-257 . [In Korean with English summary.]

Leishman, M.R., Masters, G.J., Clarke, I.P., and Brown, V.K. 2000. Seed bank dynamics: the role of fungal pathogens and climate change. Funct. Ecol. 14: 293-299. doi:10.1046/j.1365-2435. 2000.00425.x.

Mittal, R.K., Anderson, R.L., and Mathur, S.B. 1990. Microorganisms associated with tree seeds: world checklist 1990. Canadian Forest Service, Petawawa National Forestry Institute, Petawawa, Ont.

Nakagawa, M., Kurahashi, A., Kaji, M., and Hogetsu, T. 2001. The effects of selection cutting on regeneration of Picea jezoensis and Abies sachalinensis in the sub-boreal forest of Hokkaido, northern Japan. 2001. For. Ecol. Manage. 146: 15-23. doi:10. 1016/S0378-1127(00)00445-X.

Narukawa, Y., and Yamamoto, S. 2001. Gap formation, microsite variation and the conifer seedling occurrence in a subalpine oldgrowth forest, central Japan. Ecol. Res. 16: 617-625. doi:10. 1046/j.1440-1703.2001.00424.x.

O'Hanlon-Manners, D.L., and Kotanen, P.M. 2004. Logs as refuges from fungal pathogens for seeds of eastern hemlock (Tsuga canadensis). Ecology, 85: 284-289.

Pataky, N.R. 2005. Reports on plant dicease: phomopsis twig blight of juniper. Available from http://www.ipm.uiuc.edu/diseases/ series600/rpd622. [Accessed 3 June 2005.]

Saccardo, P.A., and Sydow, P. 1899. Sylloge Fungorum XIV. Padva. p.1190.

Sakamoto, Y., and Miyamoto, T. 2005. Racodium snow blight in Japan. For. Pathol. 35: 1-7.

Sanada, M., Endo, K., and Kishida, A. 1984. The effects of fungi on seedlings in natural regeneration (I): the growth of Racodium and mineral components of various kinds of leaf duff. Trans. Meet. Hokkaido Br. Jpn. For. Soc. 33: 166-168. [In Japanese.]

Sato, K., Shoji, T., and Ota, N. 1960. Studies on the snow molding of coniferous seedlings II - dark snow blight caused by Rhacodium therryanum Thuem. Bull. Gov. For. Exp. Stn. No. 124. 21-112. [In Japanese with English summary.]

Vander Wall, S.B., Kuhn, K.M., and Beck, M.J. 2005. Seed removal, seed predation, and secondary dispersal. Ecology, 86: 801-806.

Van Mourik, T.A., Stomph, T.J., and Murdoch, A.J. 2005. Why high seed densities within buried mesh bags may overestimate depletion rates of soil seed banks. J. Appl. Ecol. 42: 299-305. doi:10.1111/j.1365-2664.2005.01016.x.

Watanabe, T. 1988. Pathogenic fungi associated with forest seeds 
including Pythium species from cherry seeds. Trans. Mycol. Soc. Jpn. 29: 197-203.

Watanabe, T. 2002. Pictorial atlas of soil and seed fungi: morphologies of cultured fungi and key to species. 2nd ed. CRC Press LLC, Boca Raton, Fla.

Wicklow-Howard, M.C., and Skujins, J. 1980. Infection of Engelmann-spruce seed by Geniculodendron pyriforme in western North America. Mycologia, 72: 406-410.

White, T.J., Brums, T., Lee, S., and Taylor, J. 1990. Amplification and direct sequencing of fungal ribosomal RNA genes for phylogenics. In PCR protocols. Edited by M.A. Innis, D.H. Gelfand, J.J. Shinsky, and T.J.White. Academic Press, San Diego, Calif. pp. 315-322.

Zhong, J., and van der Kamp, B.J. 1999. Pathology of conifer seed and timing of germination in high-elevation subalpine fir and Engelmann spruce forests of the southern interior of British Columbia. Can. J. For. Res. 29: 187-193. doi:10.1139/cjfr-29-2-187. 